\title{
ACRL honors the 1998 award winners
}

\section{Recognizing professional contributions and scholarly research}

\author{
by Jack Briody
}

\section{Hirshon named winner of Atkinson Award}

Arnold Hirshon, vice provost for Information Resources at Lehigh University, is the 1998 recipient of the Hugh C. Atkinson Memorial Award. The award, $\$ 2,000$ and a citation, recognizes outstanding accomplishments of an academic librarian who has worked in the areas of library automation or library management and has made contributions (including risk-taking) toward the improvement of library services or to

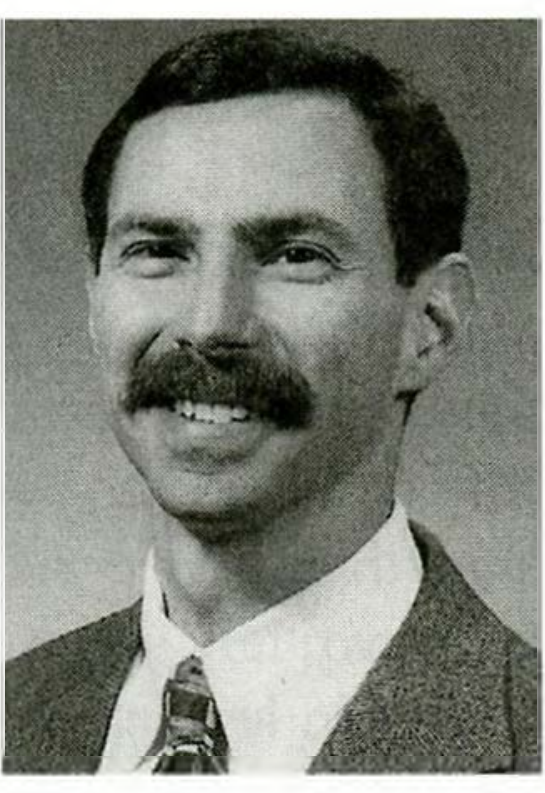

Arnold Hirshon library development or research. The Faxon Company also provides for the winner a gold giraffe pin from Tiffany's, symbolizing the "sticking-your-neck-out" aspect of the award.

Jennifer Cargill, chair of the selection committee, cited his clear thinking and implementation of innovative ideas significant to the profession as major factors in the committee's selection. Cargill said, "His leadership role in focusing today's libraries toward new efforts [in] outsourcing ... as well as his statewide efforts in networking projects [are among his chief contributions]."

Prior to his current position Hirshon served as university librarian at Wright State University, 1990-95; associate director of University Library Services at Virginia Commonwealth University, 1983-90; and assistant head of the
Cataloging Department at Duke University, 1978-83.

While at Wright State University, Hirshon oversaw the development of a Netscape-based integrated electronic access system to all resources, developed electronic text and imaging projects, and outsourced all cataloging. At Lehigh University, Hirshon has provided leadership for a restructuring initiative to merge the library and computer center and also a university-wide effort to better employ the enterprise-wide information systems.

Building on his involvement in the early stages of the OhioLINK program, he is a founding member and currently serves as chair of the Executive Committee (1996-99) of the Pennsylvania Academic Library Connection Initiative (PALCI). Both projects are state-wide initiatives to provide wide access to library collections throughout each state.

Within ALA he has been active in the Association for Library Collections \& Technical Services (ALCTS) and served as their president (1991-92), on the Board of Directors (1987-89 and 1979-85), chaired the ALCTS Budget and Finance Committee (1986-89), and has held other positions on ALCTS and ACRL committees.

The award is jointly sponsored by the Association of College and Research Libraries (ACRL), the Library Administration and Management Association (LAMA), the Library and Information Technology Association (LITA), and the Association for Library Collections \& Technical Services (ALCTS).

\section{About the author}




\section{Veaner named Academic/Research Librarian of the Year}

Allen B. Veaner, adjunct assistant professor in the School of Library Science at the University of Arizona, has been named the 1998 ACRL Academic/Research Librarian of the Year Award winner; the highest honor in academic librarianship. The award, which includes a citation and $\$ 3,000$ donated by Baker \& Taylor Books, will be presented to Veaner at a reception in his honor on Monday, June 29, 1998, from 5 to 6:30 p.m., at the ALA Annual Conference in Washington, D.C.

Committee chair Vicki Gregor said, "The value of Allen Veaner's seminal work as a pathfinder for the generation of in-

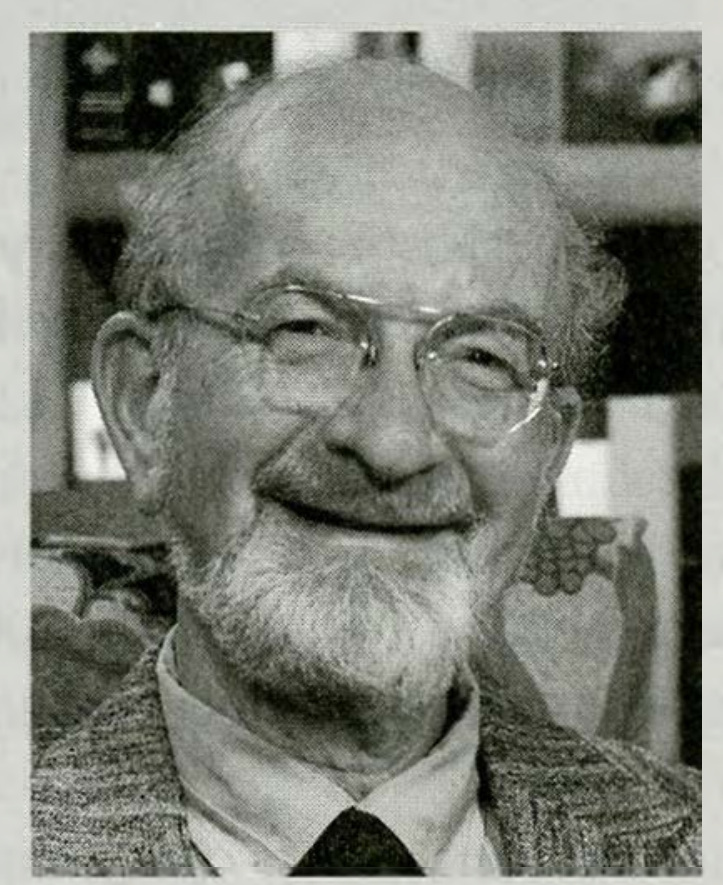

Allen B. Veaner rarely moving with the crowd. The library of the future will not - cannot-be the library of the past or even the present. To create an ever new concept of the library means always to look for the unexpected, to challenge received wisdom, to depart from the conventional, and to take risks. I like to think I have contributed modestly in encouraging our profession to do exactly that."

Prior to forming Allen B. Veaner Associates, a Torontobased library and information consulting service, in 1983 Veaner was university librarian at the University of California, Santa Barbara (1977-83); at Stanford he was assistant director for technical services (1970-77), assistant director for automation (1967-70), and chief librarian in the acquisitions department (1964-67). He also held positions at Harvard University (1957-64).

Colleagues also cited his role in ushering in library automation as one of his contributions to the profession. While at Stanford he served as the principal investigator of the BALLOTS Project, which helped form the Research Libraries Information Network (RLIN). As library director at the University of California, Santa Barbara, he introduced both OCLC and RLIN services, as well as an automated circulation system.

Veaner is a life member of ALA and has served three terms on Council in addition to serving on and chairing a number of committees. His numerous awards include the Special Libraries Association President's Award for Exceptional Service in 1988 and distinguished alumni awards from Gettysburg College in 1991 and Simmons College in 1981.

The Academic/Research Librarian of the Year Award is given annually to recognize an individual who is making an outstanding contribution to academic or research librarianship and library development. Previous winners include: James G. Neal (1997); Ralph Russell (1996); Joseph Boissé (1995); Irene Braden Hoadley (1994); William A. Moffett (1993); Carla Stoffle (1992); Richard DeGennaro (1991); and Patricia Battin (1990). 
The award will be presented on Monday, June 29, 1998, at 5 p.m., at the ACRL Awards Reception during the American Library Association (ALA) Annual Conference in Washington, D.C.

\section{Kleiner and Hamaker receive K. G. Saur Award}

Jane P. Kleiner, head of collection development at Louisiana State University (LSU) Libraries, and Charles A. Hamaker, head of technical services at the University of North Carolina, Charlotte, (UNC-C) have been named winners of the 1998 K. G. Saur Award for best article, "Libraries 2000: Transforming Libraries Using Document Delivery, Needs Assessment, and Networked Resources," in College E Research Libraries (July 1997).

William G. Jones, chair of the award committee, said "The authors' clear explanation of a set of creative research projects surrounding a timely topic of concern resulted in this bestof-year article and provides a model that can be applied in a number of different academic library settings. The article describes several projects that were undertaken at the Louisiana State University Libraries to control journal subscription expenditures while at the same time ensuring the maintenance of a high quality of service in document delivery. The authors demonstrate that careful planning can be effectively utilized to stretch library resources in times of reduced funding and rapid change."

Kleiner has been head of collection development at LSU since 1997 and served as head of remote document services and grants prior to that (1993-97). She has also been selected to receive the 1998 Reference User Services Association Margaret E. Monroe Award for outstanding contributions in adult library services and received the 1992 Reference Service Press

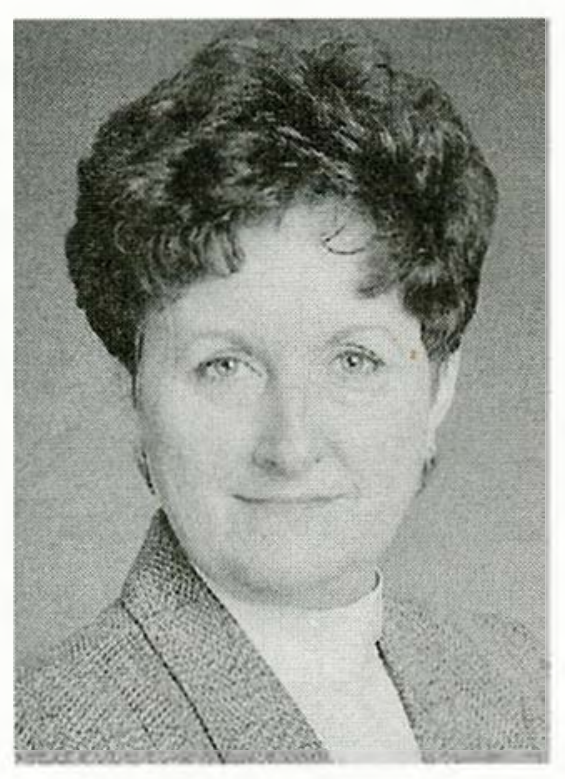

Jane P. Kleiner Award, sponsored by Reference Service Press, Inc., for an article in $R Q$.

Prior to his position at UNC-C Hamaker served as assistant dean for collection development at LSU (1986-98). In 1991 he received the Association for library Collections \& Technical Services Serials Section Bowker-Ulrich
Serials Librarianship Award for contributions to serials librarianship and received the 1991 Brigham Young University Library School Alumni Award.

The award, $\$ 50()$ and a plaque, donated by the K.G. Saur publishing company, will be presented at the ACRL Award Reception, Monday, June 29, at 5:00 p.m., during the ALA Annual Conference in Washington D.C.

\section{ISU's Dilys Morris Lazerow Fellowship}

Dilys E. Morris, assistant director of technical services at Iowa State University, has been awarded the 1998 Samuel Lazerow Fellowship for Research in Acquisitions or Technical Services in an Academic or Research Library for her work as principal investigator for the project "Technical Services Time and Cost Analysis: Development of Methodology to Compare Among Libraries."

Sponsored by the Institute for Scientific Information (ISI), the award fosters advances in acquisitions or technical services by providing fellowships to librarians for travel or writing in those fields.

The project is a cooperative effort to identify and track staff technical services' time and costs in different libraries to help identify areas where collaboration and greater information technology support can reduce costs and increase services. The current project expands on an earlier study at Iowa State University (ISU) and will apply the ISU model to four institutions' technical services to help create a time and cost analysis tool for a multi-institution environment.

The other investigators involved in the project are Cecily Johns, associate university librarian at the University of California, Santa Barbara; Flow Wilson, associate university librarian at Vanderbilt University; Christian Boissonnas, director of central technical services at Cornell University; and Brenda Dingley, assistant director for technical services at the University of Missouri, Kansas City.

Tia Gozzi, chair of the award jury, said, "Committee members liked the overall concept for the research project, acknowledging the difficulty of establishing reliable comparative cost data for technical services functions, and the benefit to all of doing so. The geographical and institutional diversity of the participants was impressive and should add to the utility of the results." 


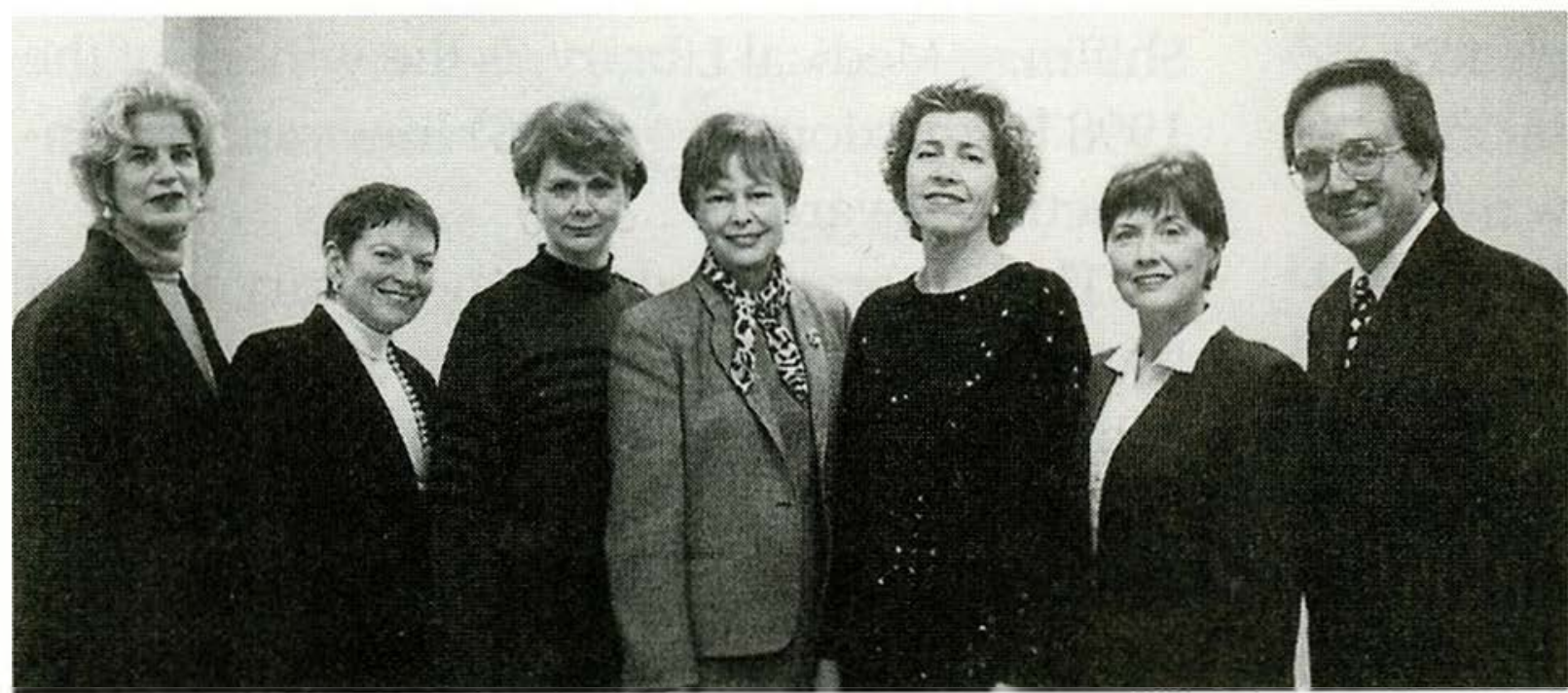

Oakton Community College's Library Staff (from L to R): Judith Mayzel, Barbara Keeley, Sandra Wittman, Beverly Drick, Joan Cichon, Susan Maltese, and Gary Newhouse. active member of CJCLS and has been instrumental in the development and delivery of more than twenty national teleconferences for professionals and para-professionals including "Dancing with Change" and "Soaring to Excellence."

The Oakton Community College Library has been chosen to receive this year's EBSCO Community College Learning Resources Program Development Award for

The award, $\$ 1,000$ and a citation, will be presented at the ACRL Award Reception, Monday, June 29, at 5:00 p.m., during the AL.A Annual Conference in Washington D.C.

\section{Fradkin and Oakton Community College receive Community College awards}

Bernard Fradkin, dean of learning resources at the College of DuPage in Glen Ellyn, Illinois, has been chosen to receive the EBSCO Community College Learning Resources Leadership Award sponsored by ACRL's Community and Junior College Libraries Section (CJCLS) and EBSCO Information Services.

Theresa Byrd, chair of the award jury, said, "Dr. Fradkin is a visionary leader and a strong advocate for community colleges. $\mathrm{He}$ is acknowledged by his colleagues for promoting technology and for creating and directing national teleconferences, especially teleconferences for library assistants."

Fradkin's career includes service as dean of instructional services at Bloomsburg University of Pennsylvania, director of the center for instructional development at the Evergreen Valley College in San Jose, as well as positions at San Jose State University and at the City University of New York. Fradkin has been involved with local and state groups in Illinois,

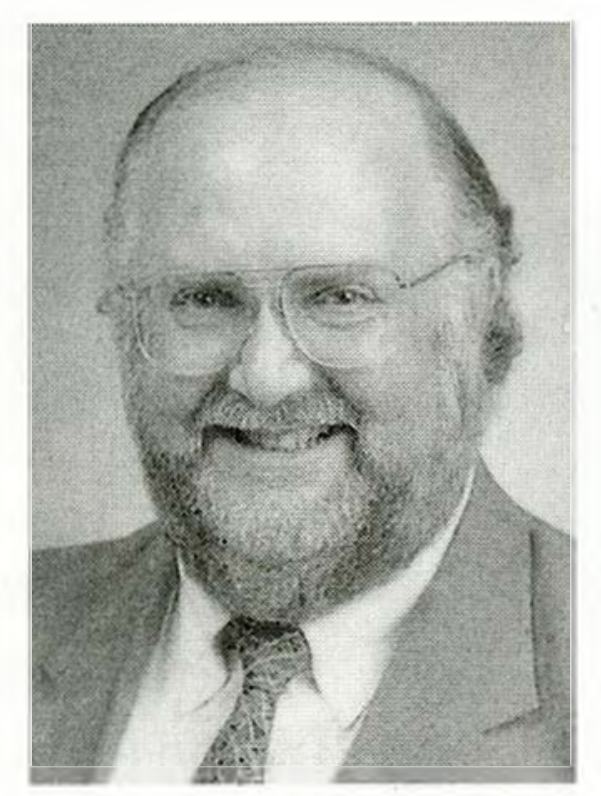

Bernard Fradkin the North Central Accreditation Association, is a co-founder and served as chair of the National Council for Learning Resources, and currently serves on the ACRL Board of Directors. He is also an its Internet training program.

The College's Internet training program was started in 1993 when the college received a grant to provide Internet access. Since that time the library has developed a campus-wide Internet/World Wide Web program that has expanded from faculty education to student workshops and assisting in developing resources to be integrated into classwork and evaluating resources on the Web.

The program has been developed by the library staff, which includes the Director of Library and Media Services, Gary Newhouse; Department Chair, Barbara Keeley; and fulltime faculty librarians Joan Cichon, Beverly Drick, Susan Maltese, Judith Mayzel, and Sandra Whittman.

The library staff has also created a page "Life Beyond Yahoo, Finding Information on the World Wide Web," http://acs.oakton. $\mathrm{edu} / \sim \mathrm{witman} / \mathrm{find} /$ finding.htm that $\mathrm{pro-}$ vides directory-style listings of resources in a number of subject areas as well as basic instruction on search engines, evaluating Web sites, and "Citing the Internet."

The awards, \$500) and a plaque, are donated by EBSCO Subscription Services and will be presented at the CJCLS business meeting during the ALA Annual Conference in Washington D.C., Saturday, June 27, 8:00 a.m.

\section{Kiewitt selected for EBSS Award}

Eva L. Kiewitt, library consultant and librarian emeritus at Regent University in Virginia Beach, Virginia, has been named winner of the 1998 Distinguished Education and Behavioral Sciences Librarian Award. This award, sponsored by ACRL and its Education and Behavioral Sciences Section (EBSS), honors a distinguished academic librarian who has made an outstanding contribution as an education and/ 
or behavioral sciences librarian through accomplishments and services to the profession.

Leslie Bjorncrantz, chair of the award jury, said, "Eva Kiewitt has had a long and distinguished career in education librarianship .... her early work with the ERIC system on vocabulary review, redesign, and evaluation; her contribution as founding co-editor of the $D i$ rectory of Curriculum Materials Centers; and her dedication to the improvement of librar-

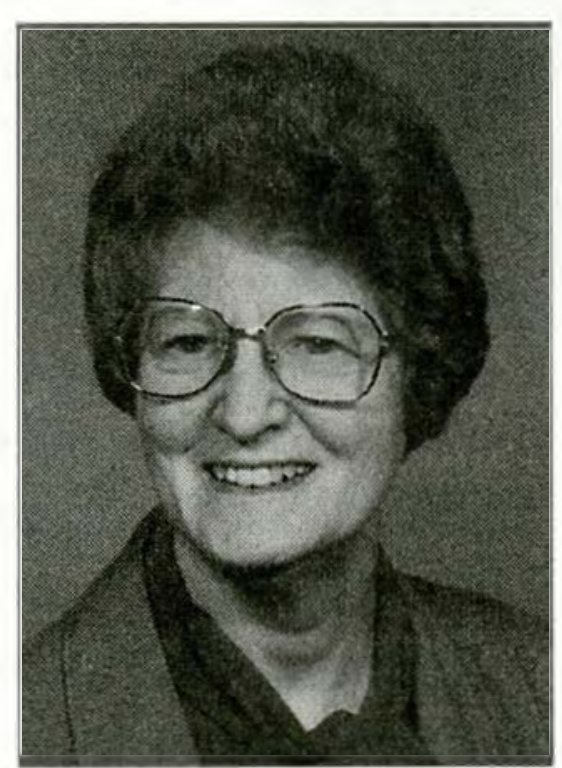

Eva Kiewitt ies both in the U.S. and abroad were chief factors in her selection her for EBSS's highest award."

Kiewitt previously served as associate dean of libraries at Regent University (1981-1994), and associate professor (1973-81) and head of the education library (1967-73) at Indiana University, Bloomington. She has held committee positions in EBSS and served as Chair (1980-81) and Secretary (1975-77) of the section. In 1997 she received the Association of Christian Librarians' Emily Russell Award, recognizing outstanding contribution to Christian librarianship.

The award (a citation) will be presented during the ALA Annual Conference in Washington D.C. at the EBSS program, Friday, June 29, from 10 a.m. to noon in the Jefferson Building of the Library of Congress.

\section{Wayne State University program wins IS Innovation Award}

The "Health Sciences Information Tools 2000" program at Wayne State University, Vera

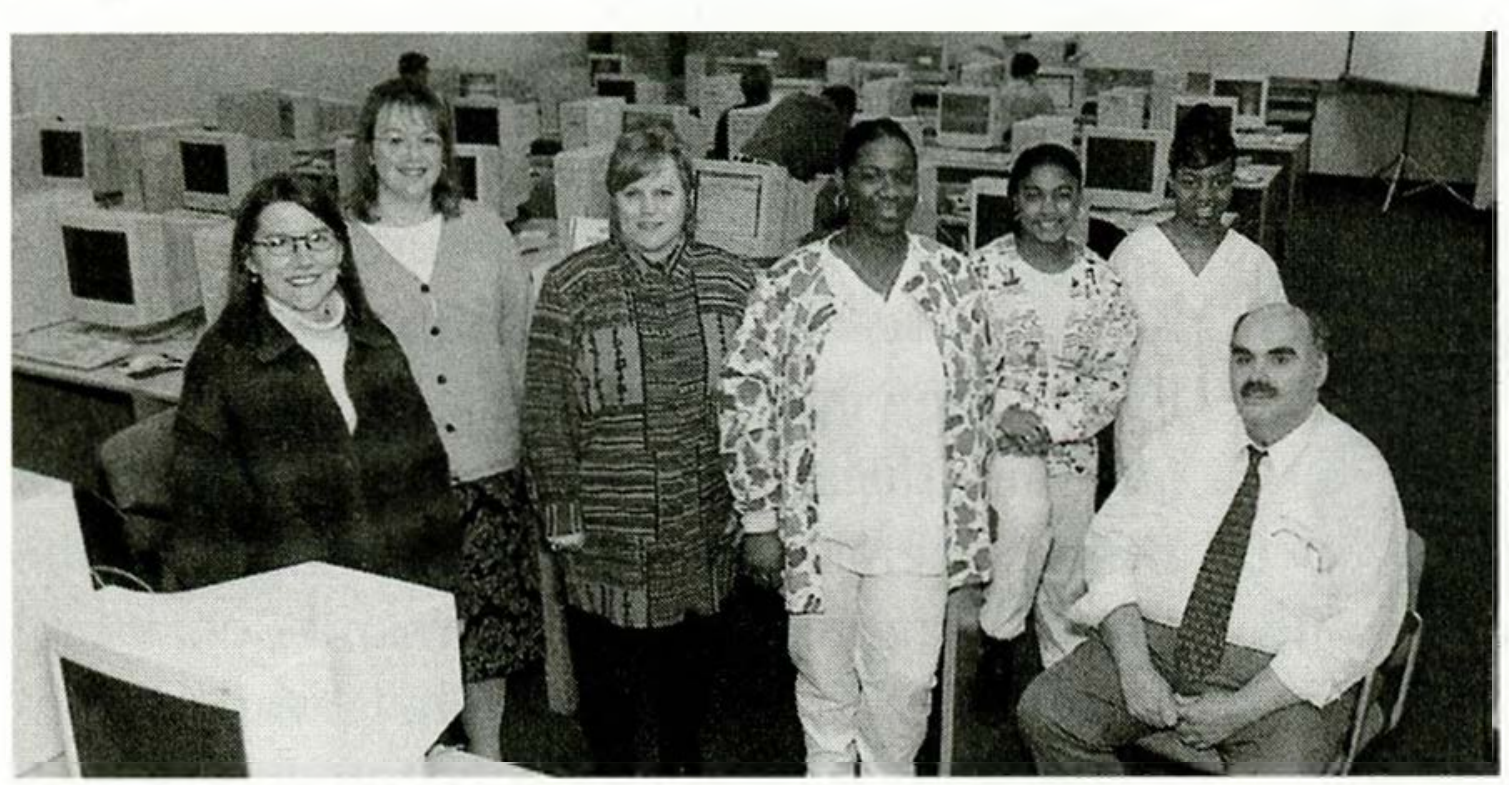

Wayne State's Health Sciences Information Tools 2000 team (from L to R): Nancy Adams, Juliet Mullenmeister, Nan Blackwell; with students: Taleia Richardson, Sarneisa Harris, Aurelia Coker; and staff member Lothar Spang.
Shiffman Medical Library, is the winner of the 1998 Instruction Section (IS) Innovation in Instruction Award.

The program is run by the library team of Nancy E. Adams, lead instructor; Lothar Spang, practicum coordinator; Nan Blackwell, practicum supervisor; Juliet Mullenmeister, instructor; and La Ventra Ellis, graduate student/ instructor. The program was first instituted as a cooperative effort between the library and the Detroit Public Schools' Crockett Career and Technical Center to provide instruction to 11th- and 12th-grade students in using tools and resources to find, evaluate, and present health-related information.

Trudi Jacobson, chair of the award committee, said, "Nancy Adams and her instructional team have developed a model program that enables vocational school students to use an academic library as the setting for developing information literacy skills. The program recognizes the critical need to prepare students for the workforce of the 21 st century."

The Information Tools 2000 program is funded by the American Honda Foundation in Torrance, California, and has been expanded to provide instruction in Michigan's recently created Health Education and Related Technology (HEART) Academy.

The award, a citation, will be presented at the IS dinner during the ALA Annual Conference in Washington, D.C., Friday, June 26, 1998.

\section{Arp named Dudley Instruction Librarian}

Lori Arp, head of Central Reference and Media Libraries at the University of Colorado (UC) at Boulder, is the 1998 winner of the Instruction Section's Miriam Dudley Instruction Librarian Award. The award, honoring the woman whose pioneering efforts in the field of library instruction led to the formation of ACRL's Instruction Section, recognizes an individual librarian who has made an especially significant contribution to the advancement of library instruction in a college or research institution.

Loanne Snavely, chair of the award jury, said, "Arp has been a key player in shaping the issues facing instruction librarians over the past 15 


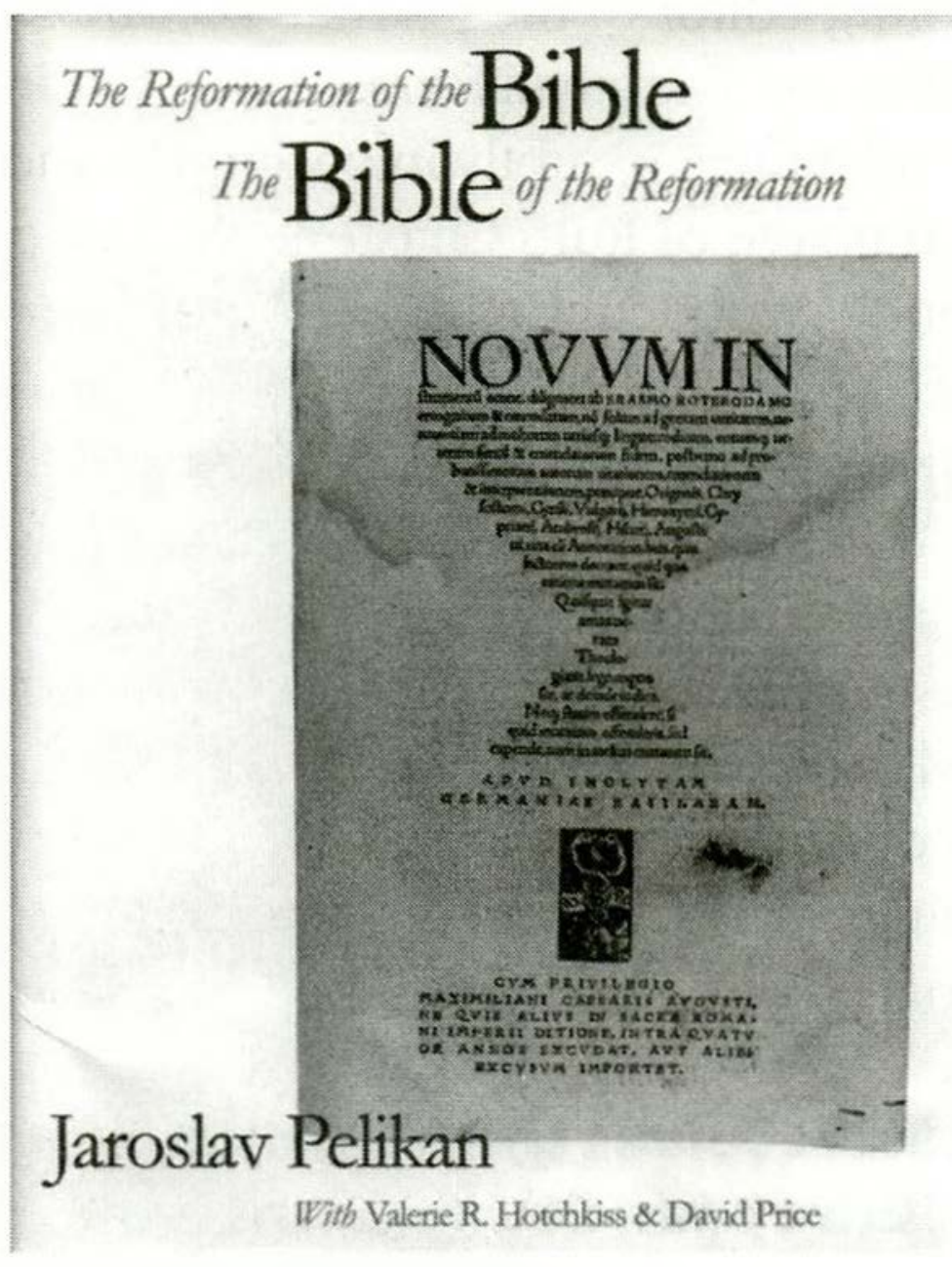

years, and has made significant contributions in all four areas of the Dudley award criteria: program development, publication, professional leadership, and education. Her presentations and publication have gained national and international recognition. These, along with her programmatic innovations and leadership in the Instruction Section, have had a wide ranging impact"

Arp is currently an associate professor at UC and previously served as coordinator of instruction services (1985-90) and deputy assistant director and CARL user representative (1989) at the University of Colorado at Denver/Auraria Library; and assistant professor of library administration at the University of Illinois at Urbana (1982-85). Within the ALA she has served on a number of ACRL committees, chaired the ACRL Leadership Retention Task Force (1995-97), served on

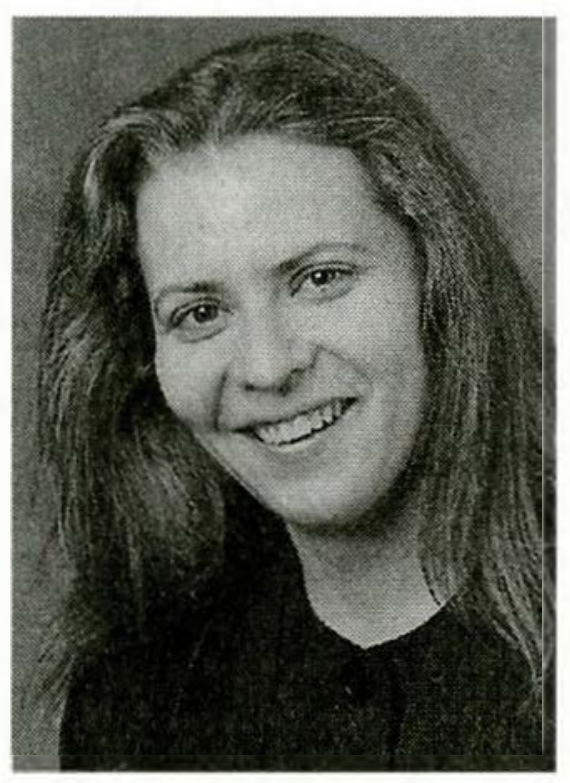

Lori Arp and chaired committees within IS, and served as chair of the IS Executive Committee (199394), in addition to holding other elected positions within the section. In 1996 she was named Colorado Librarian of the Year by the Colorado Library Association.

The award, $\$ 1,000$ and a plaque, is donated by JAI Press on behalf of its journal Research Strategies. It will be presented during the ALA
Annual Conference in Washington D.C. at the IS program, Sunday, June 28, at 2:00 p.m.

\section{Gasaway wins Marta Lange/CQ Award}

Laura N. "Lolly" Gasaway, director of the law library and professor of law at the University of North Carolina at Chapel Hill (UNC-CH), has been named the 1998 recipient of the Marta Lange/CQ Award. The award is administered by ACRL's Law and Political Science Section (LPSS) and sponsored by Congressional Quarterly in honor of former LPSS chair Marta Lange.

Rosemary Allen Little, chair of the award committee, said, "Professor Gasaway has excelled at mastering complex law-related subjects and engaging a wide variety of audiences locally and nationwide with her superb demystifying presentations."

Among Gasaway's contributions cited by the committee and her colleagues were her workshops and publications on copyright, women in the law, sexual harassment, and cyberspace law. She has also been active in the American Association of Law Libraries, the Special Libraries Association, the American

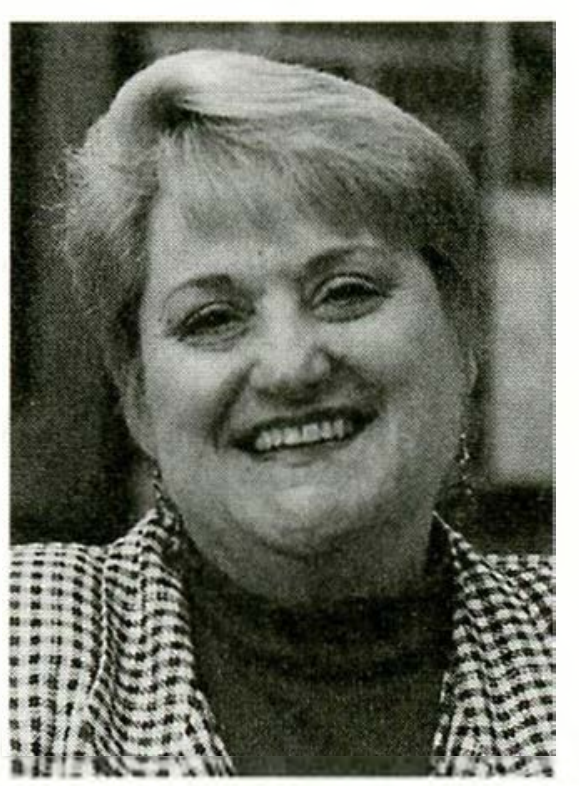

Laura N. Gasaway Association of Law Schools, and the American Bar Association.

Prior to coming to the UNC-CH in 1985 , she served as director of the law library and professor of law at the University of Oklahoma (1975-84) and as law librarian and assistant professor of law at the University of Houston (1973-75).

The award, $\$ 1,000$ and a citation, is donated by Congressional Quarterly and will be presented at the LPSS lunch, Sunday, June 28, at 12:30 p.m., during the ALA Annual Conference in Washington D.C.

\section{Exhibition catalogs recognized by Leab Awards}

There are three winners for the 1998 Katharine Kyes Leab and Daniel J. Leab American Book Prices Current Exhibition Catalogue Awards. In category one (expensive), the winner is The Reformation of the Bible, The Bible of the Reforma- 


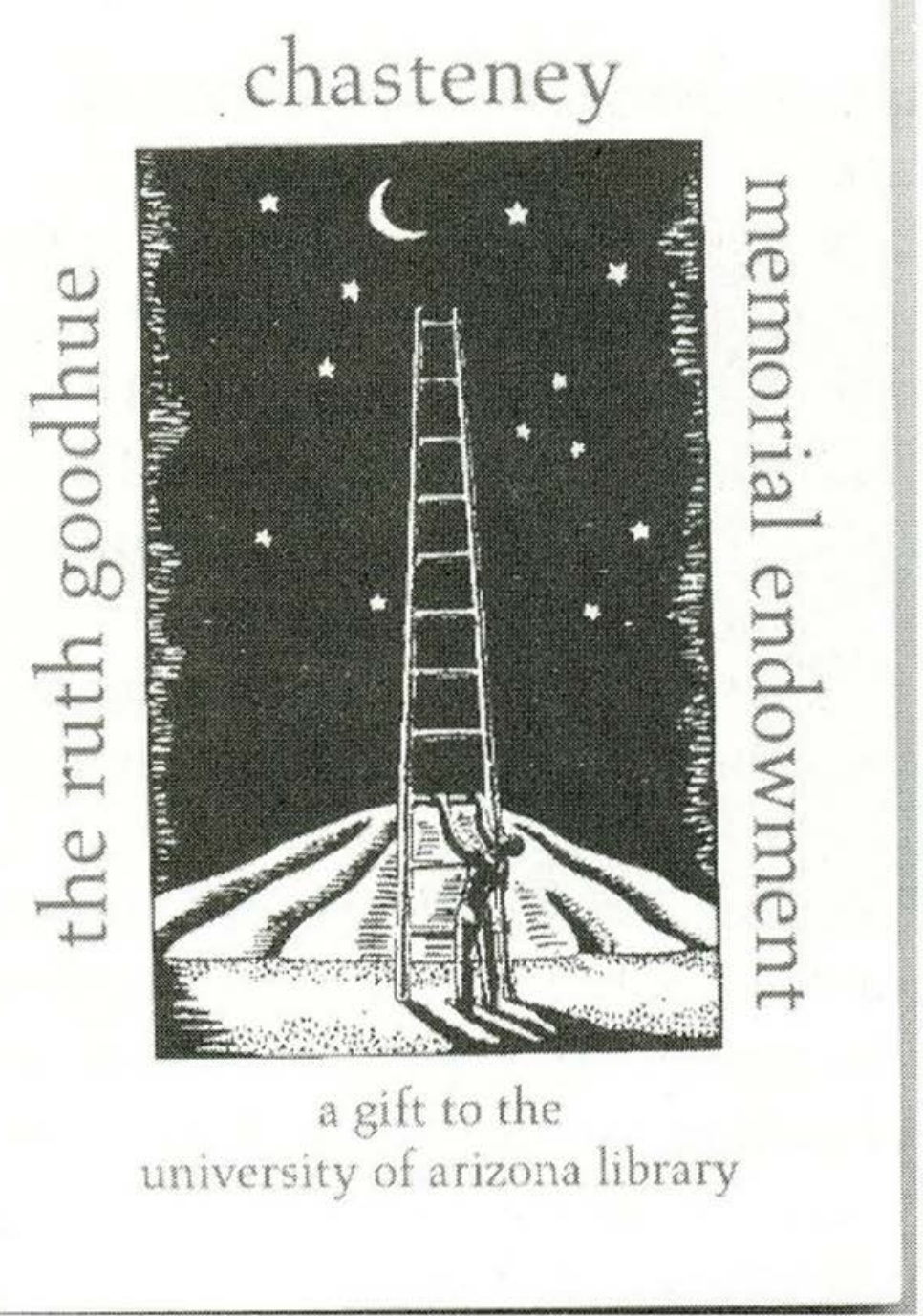

tion, by Jaroslav Pelikan and David Price with Valerie Hotchkiss, submitted by the Bridwell Library, Southern Methodist University.

In selecting the catalog the committee said, "This impressive example of scholarly thoroughness not only represents what will be a lasting contribution to the study of the Bible and the Reformation, but the fundamental genius of library exhibitions to reveal the essential relationship of the artifact and intellectual valorization."

In category two (moderate), the committee selected The Library of the Jewish Theological Seminary of America's Kehillat Ha-Kodesh: Creating the Sacred Community: The Roles of the Rabbi, Cantor, Mohel and Shohet in Jewish Communal Life. The committee said, "The text of the catalog is fascinating and original, composed with a clear narrative gift, and thus accessible to a broad range of readers. Every reader will learn much about how community spirit is fostered by these four central figures of Judaism. The catalog beautifully reproduces every broadside, engraving, portrait, document, book, and manuscript within the exhibition-many on view for the first time."

In category three (inexpensive), For love of Ruth by the University of Arizona Library, Special Collections, is this year's winner. The committee cited the catalog as "a winning example of a library exhibition that sheds a warm light on the relationship of special collections and a special donor, Ruth Chasteney, a former managing editor of the journal The Architectural Forum. The small format conveys directness and intimacy, subtly intensified by the repeated image of Ruth Chasteney's 'ladder to the moon' woodcut bookplate, and, more directly, by the personal essays by Robert Chasteney, with whom she shared a lifelong love of books."

Printed citations given by ACRL's Rare Books and Manuscripts Section will be presented to the winners following the RBMS program during the ALA Annual Conference in Washington D.C., Sunday, June 28, 1998, at 4:00 p.m.

\section{Garrett receives the Martinus Nijhoff West European Study Grant}

Jeffrey Garrett, bibliographer, western languages and literatures at Northwestern University in Evanston, Illinois, has been awarded the Martinus Nijhoff West European Specialists Study Grant for 1998. The grant of 10,000 Dutch guilders, covers air travel to and from Europe, transportation in Europe, and lodging and board in selected sites for a period not to exceed 14 consecutive days.

Garrett will use the grant to travel to Munich to do research on "The End of Monastery Libraries in Bavaria and the Birth of Modern Library Science, 1802-1814."

Diana Chlebek, chair of the award committee, said "Garrett's proposal outlines a well-conceived research project that will make a valuable and insightful scholarly contribution to the history of librarianship relating to Western Europe."

The focus of Garrett's study will be on "the fate of confiscated Bavarian monastic libraries between 1802-14, their incorporation into the collections of the Bavarian Staatsbibliothek, and the impact of these events on the founding of modern library science."

The award will be presented at the WESS membership meeting on Monday, June 29, 1998, at 11:30 a.m. during the ALA Annual Conference in San Francisco.

\section{Award nominations}

Guidelines and submission information for ACRL's awards are available at http:// www.ala.org/acrl/award2.html or by contacting Jack Briody at (800) 545-2433, ext 2516 or jbriody@ala.org. Most awards have a December 1 submission deadline. 


\section{State of the Art Technology for Information Management}

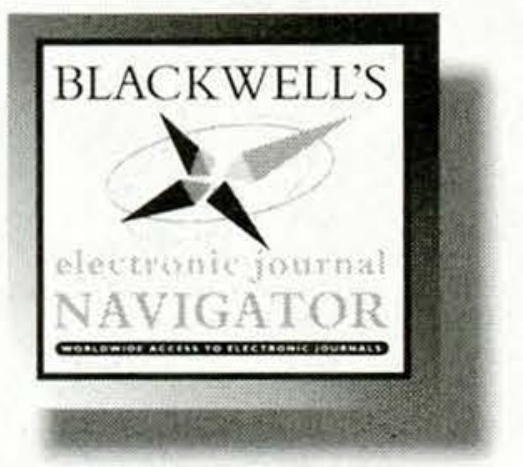

BLACKWELL'S ELECTRONIC JUURNAL NAVIGATロR

ACCESS TO ELECTRONIC JUURNALS THROUGH A SINGLE WEB-BASED USER INTERFACE.

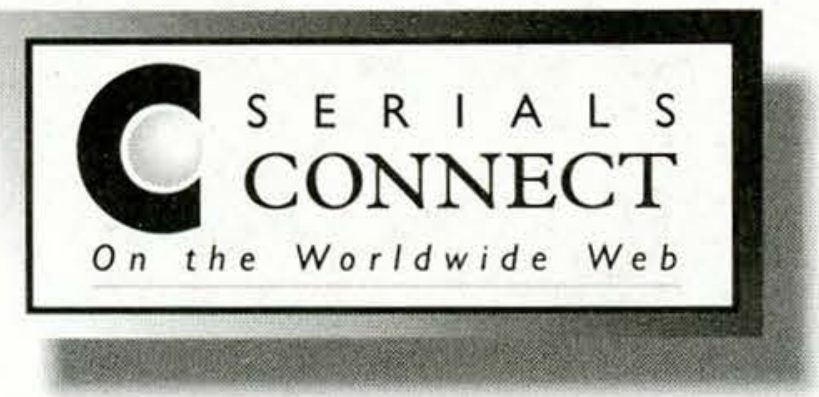

SERIALS CDNNECT DN THE WDRLDWIDE WEB

EASY-TO-USE WORLDWIDE LINK TO QUR UNIQUE DATABASE IF SERIALS AND SERIES INFIRMATION.

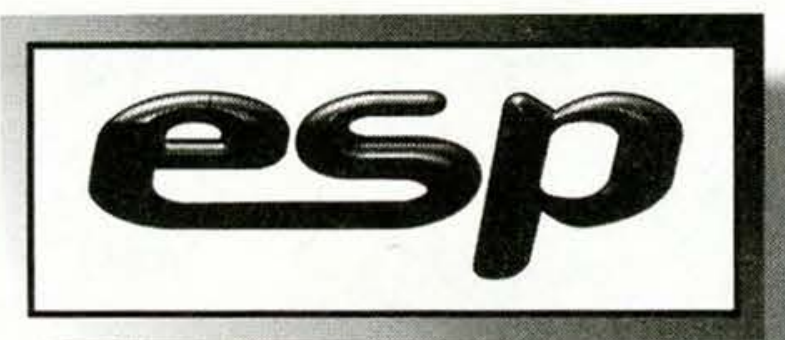

\section{ELECTRONIC SUBSCRIPTIDN PRDVIDER}

ACCESS TO A RANGE IF CD-ROM DATABASES FROM A VARIETY DF PUBLISHERS IVER THE INTERNET.

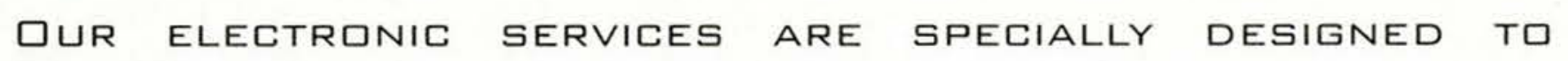
PRIVIDE A SINGLE SUURCE OF ELECTRONIC SUBSCRIPTION INFIRMATION TO ACADEMIC AND RESEARCH LIBRARIES. WE WORK IN CLOSE PARTNERSHIP WITH CUSTIMERS AND PUBLISHERS TO PROVIDE PRODUCTS AND SERVICES DESIGNED FOR INDIVIDUAL CUSTOMER NEEDS.

\section{BLACKWELL'S}

INFORMATION SERVICES

New Jersey Sales Office

PO Box 1257, Blackwood, NJ 08012 • Phone: 800-458-3706 • Fax: 609-232-5397

http://www.blackwell.co.uk 
